\title{
Descriptions of three species of muscid larvae and eggs newly recorded from cow dung in Japan \\ (Diptera : Muscidae)*
}

\author{
Mitsuhiro IwASA** \\ Laboratory of Entomology, Obihiro University, Obihiro, Hokkaido O80, Japan
}

(Received: September 22, 1979)

\begin{abstract}
The $3 \mathrm{rd}$ instar larvae and eggs of one species of the genus Polietes and two species of the genus Hydrotaea are described and figured. These are $P$. nigrolimbatus (Bonsdorff), H. albipuncta (Zetterstedt), and $H$. meteorica (Linnaeus). Among these, $P$. nigrolimbatus and $H$. meteorica are newly described, and $H$. albipuncta is redescribed.
\end{abstract}

\section{INTRODUCTION}

Hitherto three species of the genus Polietes and 8 species of the genus Hydrotaea were recorded from Japan. Among these, $P$. albolineatus (Fallén), P. nigrolimbatus (Bonsdorff), $H$. meteorica (Linnaeus) are known to occur from cow dung in Japan. $H$. albipuncta (Zetterstedt) which is newly recorded from Japan in this study also occurs from cow dung. The larva of $P$. albolineatus was described in detail by Keilin and Tate (1930). The larvae and eggs of $H$. albipuncta were described by Lobanov (1968) and Hammer (1941), respectively. However, the larvae and eggs of $P$. nigrolimbatus and $H$. meteorica have been never known untill now. In the present papar, the author describes the $3 \mathrm{rd}$ instar larvae and eggs of $P$. nigrolimbatus and $H$. meteorica and redescribes those of H. albipuncta.

\section{MATERIAL AND METHODS}

The female flies were collected by sweeping

* Contribution No. 96 from the Laboratory of Entomology, Obihiro University

** Present address: Department of Medical Zoology, Faculty of Medicine, Tokyo Medical and Dental University, Bunkyo-ku, Tokyo 113, Japan

** 岩佐光啓 : 帯広畜産大学昆虫学教室 (干080 北海 道帯広市稲田町) net in pastures of Obihiro, Hokkaido. The captured flies were identified and kept in plastic cups $(6 \times 12 \mathrm{~cm})$ for the oviposition. The obtained eggs were placed on fresh cow dung in plastic cups $(4 \times 8 \mathrm{~cm})$ and reared to mature larvae. Some coprophagous larvae of Diptera were feeded for breeding the larvae of $H$. albipuncta and $H$. meteorica. The mature larvae were killed in boilling water and preserved in $70 \%$ ethanol for study.

\section{DESCRIPTION}

\section{Polietes nigrolimbatus (Bonsdorff, 1866)}

(Figs. 1, 4-9)

Polietes nigrolimbatus Bonsdorff, 1866, Finlands Tråving. Ins. (Dipt.), 2, p. 172: Aricia.

Egg. Length about $2.5 \mathrm{~mm}$, width $0.8 \mathrm{~mm}$; white colour; the chorion sculpture with a reticulation of hexagonal meshes; the sole is long and with faint hexagons.

Third instar larva. Large sized, fully mature larvae 13 to $15 \mathrm{~mm}$ in body length; yellow colour; tapering anteriorly and truncated posteriorly; 2 nd segment with broad microscopic spine band around anterior margin, 6 th to 12 th segment with ventral papillae; anal papillae and subanal papillae developed; postanal papilla with spines; numerous small papillae present on posterior 

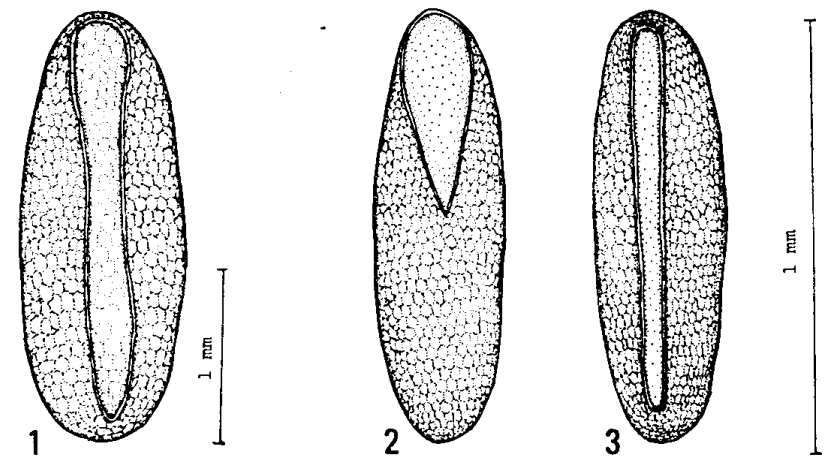

Figs. 1-3 The eggs

1. Polietes nigrolimbatus; 2. Hydrotaea albipuncta; 3. H. meteorica

part of anal plate.

Anterior spiracles: With 8 to 11 branches. Posterior spiracles: Broad kidney-shaped; peritreme closed and heavily pigmented; button clear inside of the peritreme; slits sinuate. Cephalopharyngeal sclerite: Mouth hooks sharply pointed; accessory sclerites consist of a pair of oral bars and a pair of anterior rods with heavily pigmented; cutaneous teeth absent; pharyngeal sclerite strongly pigmented; dorsal cornua slender and shorter than ventral cornua, ventral cornua with prominent triangular projection on the upper margin; longitudinal ventral pharyngeal ridges present; dental sclerite without ventral bridge.

Biological notes: The adult of this species closely resembles to that of $P$. lardarius (Fabricius). Séguy (1923) reported that the larvae of $P$. lardarius were carnivorous. Keilin and Tate (1930) mentioned that the larvae of this species were semi-carnivorous. But the larvae of $P$. nigrolimbatus seems to be coprophagous. The eggs are laid on the underside of the dung or the ground beneath the dung cake.

\section{Hydrotaea albipuncta (Zetterstedt, 1845)}

(Figs. 2, 10-15)

Hydrotaea albipuncta Zetterstedt, 1845, Dipt. Scand., 4, p. 1581: Aricia; Hammer, 1941, Vidensk. Medd. Dansk. Naturhist. Foren. Kobh., 105, pp. 118-119: Egg; Lovanov, 1968, Zool. J. Moscow, 47, pp. 85$90: 3 \mathrm{rd}$ instar larva.

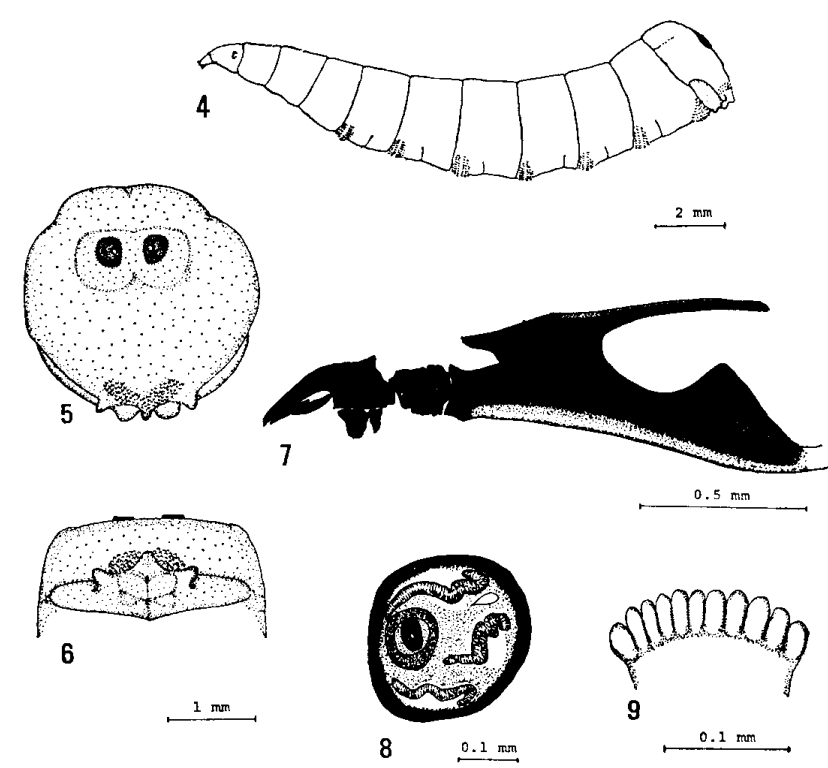

Figs. 4-9 The third instar larva of Polietes nigrolimbatus

4. Lateral view; 5. Posterior view of 12 th segment; 6. Ventral view of 12 th segment;

7. Lateral view of cephalopharyngeal sclerite;

8. Posterior view of posterior spiracle; 9 .

Lateral view of anterior spiracle

Egg. Length $0.9-1.0 \mathrm{~mm}$, width $0.2-0.3$ $\mathrm{mm}$; white colour; the chorion sculpture consists of a reticulation of distinct hexagonal meshes; the sole is short and hexagons invisible.

Third instar larva. Body length 6 to 7 $\mathrm{mm}$; yellow colour; tapering anteriorly and truncated posteriorly; ventral surface of 6 th segment with microscopic spines, those of 7 th to 11 th segments with microscopic spines and papillae; anal papillae and extra-anal papillae present; subanal and postanal papillae absent; the sculpture on the posterior surface of 12 th segment with squamosous pattern; posterior spiracular plates slightly raised on stalks.

Anterior spiracles: With 3 branches. Posterior spiracles: Small sized and weekly pigmented; slits elongate oval; button not distinct. Cephalopharyngeal sclerite: Mouth hooks pointed sharply; accesory sclerites consist of a pair of oral bars and a pair of anterior rods; anterodorsal process pointed; dorsal cornua slender and slightly curved downward, ventral cornua shorter than dorsal cornua; longitudinal ventral pharyngeal ridges absent; dental sclerite without ventral bridge. 
Biological notes: The larvae of this species seems to be carnivorous. They feed on the larvae of Diptera which live in the same cow dung. Adult flies gather on pasturing cattle. The eggs are generally deposited on the soil or grass beneath the dung cake in pastures.

\section{Hydrotaea meteorica (Linnaeus, 1758)}

(Fig. 3. 16-21)

Hydrotaea meteorica Linnaeus, 1758, Syst. Nat., 10, p. 597 : Musca.

Egg. Length $1.0-1.1 \mathrm{~mm}$, width $0.3-0.35$ $\mathrm{mm}$; white colour; the chorion sculpture with a distinct reticulation of hexagonal meshes; the sole is long and without hexa-
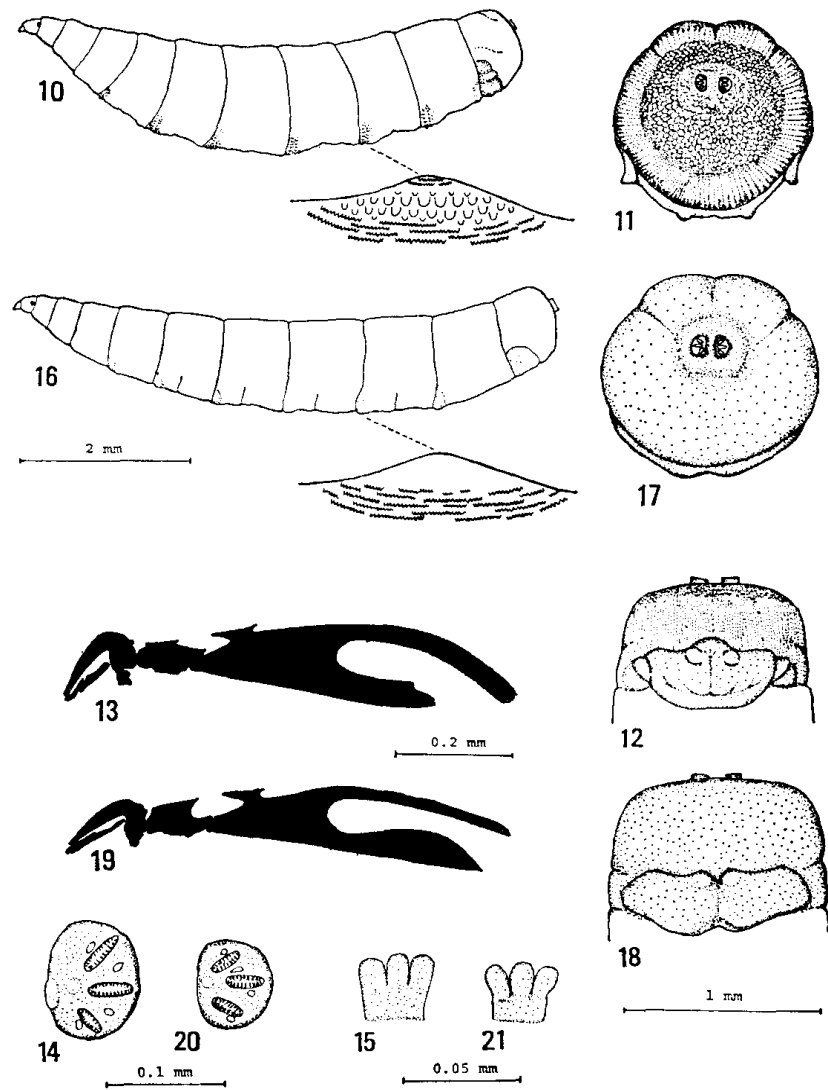

12

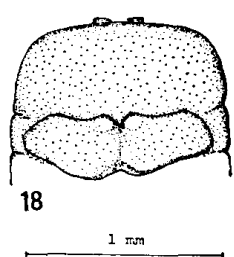

Figs. 10-21 The third instar larvae of

Hydrotaea albipuncta and $H$. meteorica.

10-15. H. albipuncta

16-21. H. meteorica

10, 16. Lateral view of $3 \mathrm{rd}$ instar larva;

11,17 . Posterior view of 12 th segment ; 12 ,

18. Ventral view of 12 th segment; $13,19$.

Lateral view of cephalopharyngeal sclerite; 14, 20. Posterior view of posterior spiracle; 15,21 . Lateral view of anterior spiracle gones.

Third instar larva. Body length about 7 $\mathrm{mm}$; yellow colour; tapering anteriorly and truncated posteriorly; 6 th to 11 th segments with microscopic spines on the ventral surface; ventral papillae absent; anal papillae inconspicuous; extra-anal, subanal and postanal papillae absent; the sculpture on the posterior surface of 12 th segment without squamosous pattern; posterior spiracular plates slightly raised on stalks.

Anterior spiracles: With 3 branches. Posterior spiracles: Small sized and kidneyshaped with weekly pigmented; slits elongate oval; button not distinct. Cephalopharyngeal sclerite: Mouth hooks pointed sharply; accesory sclerites consist of a pair of oral bars and a pair of anterior rods; anterodorsal process pointed; dorsal cornua slender and longer than ventral cornua; longitudinal ventral pharyngeal ridges absent; dental sclerite without ventral bridge.

Biological notes: The feeding habits of this larvae are similar to those of $H$. albipuncta. The larvae seems to be carnivorous. They prey upon the fly larvae living in the cow dung. It was impossible to breed them to maturity on pure dung. The adult behavior also is similar to that of $H$. albipuncta. They gather on the pasturing cattle and human body. The eggs are deposited on the soil or grass beneath the dung cake.

\section{ACKNOWLEDGEMENTS}

The author wishes to express his sincere thanks to Prof. Y. Nishijima of Obihiro University, for his kind advice and reading the manuscript. The author also would like to express his deep appreciation to Prof. R. Kano and Dr. S. Shinonaga of Tokyo Medical and Dental University; Mr. T. Hasegawa, Tohoku National Agricultural Experiment Station, for their kind identification and valuable suggestions.

\section{REFERENCES}

Hammer, O. (1941): Biological and ecological investigation on flies associated with pasturing cattle and their excrement. Vidensk. Medd. Dan. Naturhist. Foren. Khobenhavn, 105 : 141393.

Keilin, D. and P. Tate, (1930): On certain semicarnivorous Anthomyid larvae. Parasitology, 
22 : 168-181.

Lobanov, A. M. (1968): The morphology of the third instar larvae of the synanthropic flies from the genus Hydrotaea R. D. (Diptera: Muscidae). Zool. J. Moscow, 47 : 85-90.

Séguy, E. (1923): Faune de France. Dipteres Anthomyides. 393 pp. Paris.

\section{摘 要}

牛粪より発生するクロハナバエ属（genus Polietes Rondani) の 1 種とモモエグリ ハナバェ属 (genus Hydrotaea R. D.) の 2 種の 3 令幼虫および卵について (双翅目，イエバエ科)

著者は, 牛糞より発生するクロ八ナバエ属の1種
Polietes nigrolimbatus (オオクロハナバェ) とモモエグ リハナバェ属の 2 種, Hydrotaea albipuncta, $H$. meteorica (キリガクレメマトイ) の 3 令幼虫および卵を 記載した. P. nigrolimbatus の幼虫は Fig. 4-9 のごと く, 肚板後方に多くの小さな突起を有し, 咽頭骨格は強 く硬化し，腹翼の上縁は著しく三角状に突出しているな どの特徴があり，わが国に生息する Polietes 属の 1 種 P. albolineatus（二セセジロハナバェ）とは容易に区別 できる．またこの幼虫は，近縁でかつ肉食性として知ら れている P. lardarius (Fabricius) の幼虫に類似して いるが，P. nigrolimbatus は粪食性である. H. albipuncta と H. meteorica の両種の幼虫の間には, 第 12 節の後方表面のらろこ状の模様の有無, 第 6 節より 第 11 節までの腹部の棘帯と突起，肚板の 突起などに差異 がみられ，これらにより種の同定が可能である。この両 種の幼虫は牛糞を与えただけでは成熟しないことなどか ら obligate な肉食性と考えられる。 